\title{
Evidence for iron-regulated cyanobacterial predominance in oligotrophic lakes
}

\author{
RYAN J. SORICHETTI*, IRENA F. CREED* AND CHARLES G. TRICK*,+ \\ *Department of Biology, Western University, London, ON, Canada \\ ${ }^{+}$Schulich School of Medicine and Dentistry, Western University, London, ON, Canada
}

\section{SUMMARY}

1. Cyanobacterial harmful algal blooms (cyanoHABs) are most often associated with large eutrophic lakes. In the past decade, an increase in the incidence of cyanoHABs in small oligotrophic lakes within the Laurentian Great Lakes-St. Lawrence River Basin has been documented. We explored macro- and micronutrient conditions during peak phytoplankton biomass that result in high cyanobacterial densities. 2. We hypothesised that the availability of biologically available iron $(\mathrm{Fe})$ both limits the assimilation of phosphorus by competing taxa and selects for the predominance of cyanobacteria.

3. We tested this hypothesis with a comparative study of 25 oligotrophic lakes in central Ontario, Canada. These lakes were sampled during peak phytoplankton biomass for 3 years (from 2009 to 2011) for concentrations of total phosphorus (TP), total nitrogen (TN), ammonium $\left(\mathrm{NH}_{4}^{+}\right)$, nitrate $\left(\mathrm{NO}_{3}^{-}\right)$, total dissolved $\mathrm{Fe}$ (TDFe) and $\mathrm{pH}$ for comparison with phytoplankton community biomass and composition. 4. Correlation analyses indicated that predominance of cyanobacteria was assured at all TP levels when the availability of Fe was low. Proportionally high cyanobacterial density occurred at relatively low TP in lakes with a molar ratio of dissolved inorganic N (DIN):TP of 8:1 and a modelled ferric Fe concentration $<1.0 \times 10^{-19} \mathrm{M}$ at which cyanobacteria have been shown to be competitive for $\mathrm{Fe}$ in laboratory experiments. Regression tree analysis confirmed the minimal influence of $\mathrm{P}$ and $\mathrm{N}$, implying that cyanobacteria thrive in low Fe environments.

5. Our findings suggest that an increased susceptibility of oligotrophic lakes to cyanobacterial bloom formation is based on the presence of cyanobacteria that have adapted sufficiently to low $\mathrm{Fe}$ environments and are able to multiply rapidly when pulses of $\mathrm{P}$ are made available to the ecosystem. Physiologically prepared transitionary cyanobacteria do not have to compete with the eukaryotic species but rather exploit the new $\mathrm{P}$ and replicate faster.

Keywords: cyanobacteria, iron, nitrogen, oligotrophic lakes, phosphorus

\section{Introduction}

The ecosystem services provided by freshwater lakes are threatened by photosynthetic cyanobacteria (Keeler et al., 2012), which are widely distributed in temperate and boreal freshwater ecosystems (Fogg et al., 1973). Cyanobacteria in lakes range from low biomass picocyanobacteria, to 'transitionary' diverse communities containing large filaments and colonies, to high biomass 'mono-specific' communities (cyanoblooms) (Paerl \& Huisman, 2009). The term 'bloom' is often defined as dominance by cyanobacteria, constituting $>50 \%$ of phytoplankton biomass, regardless of whether surface accumulation is visible (Downing, Watson \& McCauley, 2001). At higher levels of biomass, cyanobacteria have the capacity to produce toxic secondary metabolites known as cyanotoxins, often classified as neurotoxins and hepatotoxins, that may pose serious human, animal and ecosystem health concerns (Mur, Skulberg \& Utkilen, 1999). Under these situations, the term 'cyanobacterial harmful algal bloom' (cyanoHAB) is used.

In oligotrophic lakes, the low nutrient supplies have traditionally led to dominance by picocyanobacteria (Callieri \& Stockner, 2000). However, even in

Correspondence: Irena F. Creed, Department of Biology, Western University, 151 Richmond Street, London, ON N6A 5B7, Canada. E-mail: icreed@uwo.ca 
oligotrophic lakes, the dominance by picocyanobacteria can be usurped by larger, filamentous or colonial cyanobacteria with small changes in light and competition for nutrient flux (Callieri \& Stockner, 2000). These transitionary cyanobacteria represent the low biomass cyanobacteria that may be stimulated by other environmental factors to form cyanoHABs. Recent trends in cyanobloom dynamics indicate that our understanding of important factors contributing to cyanobacterial growth is insufficient. Cyanoblooms are now being reported in oligotrophic, macronutrient poor freshwater systems including Gloeotrichia echinulata blooms in north-eastern U.S.A. (Carey, Weathers \& Cottingham, 2008) and Anabaena spp., Aphanizomenon spp., Microcystis spp., Gloeotrichia spp. and Oscillatoria spp. blooms in Ontario Canada (Winter et al., 2011). It is becoming clear that cyanoblooms are no longer strictly associated with eutrophication.

Most models dealing with cyanobacteria-eukaryotic phytoplankton competition or dominance are based on macronutrient use efficiency and the consequences of adding more phosphorus $(\mathrm{P})$ and nitrogen $(\mathrm{N})$ into a lake ecosystem. Reports of emerging cyanobloom occurrence have increased over the past several decades and are thought to be due to increased P supply as a result of land use and land cover change (Foley et al., 2005) and/or global N enrichment (Bergström \& Jansson, 2006). However, these explanations provide little insight into cyanobloom occurrence in unmanaged oligotrophic lakes with no increase in point or non-point sources of nutrients that would lead to increased nutrient loading (Carey et al., 2008). In fact, stoichiometric studies of controls on cyanobacterial biomass have often failed to account for micronutrients such as iron $(\mathrm{Fe})$, which has been shown to contribute significantly to cyanobacterial growth in laboratory studies (Kerry, Laudenbach \& Trick, 1988; Wilhelm, 1995) and in lakes (Vrede \& Tranvik, 2006; Downs, Schallenberg \& Burns, 2008; Molot et al., 2010). Bioavailable $\mathrm{Fe}$ in aerobic oligotrophic surface waters exists in its ferric form $\left(\mathrm{Fe}^{3+}\right)$, which is reduced to its ferrous form $\left(\mathrm{Fe}^{2+}\right)$ at the cell surface prior to assimilation (Kranzler et al., 2011). Cyanobacteria require Fe for nitrogenase activity in $N_{2}^{-}$fixation (Murphy, Lean \& Nalewajko, 1976) and for nitrate reductase activity in $\mathrm{N}$-assimilation (Kranzler et al., 2011).

The purpose of this study was to determine whether the availability of $\mathrm{Fe}$ can be related to the presence of cyanobacteria in oligotrophic lakes in a region with increased unexplained occurrences of cyanoblooms (Winter et al., 2011). For a set of oligotrophic lakes with similar physical characteristics but different macro- and micronutrient conditions, we set out to determine whether $\mathrm{P}$ or $\mathrm{N}$ limits cyanobacterial biomass and what role ferric Fe may play in alleviating $\mathrm{P}$ - or N-limitation on cyanobacterial biomass. Our hypothesis was that cyanobacteria will predominate in the community when concentrations of ferric Fe are restricted; specifically, where ferric $\mathrm{Fe}$ is not readily accessible to eukaryotic phytoplankton (ferric Fe concentrations $<1.0 \times 10^{-19} \mathrm{M}$ ). A better understanding of $\mathrm{P}, \mathrm{N}$ and Fe limitation on cyanobacterial biomass will provide insight into the risk of cyanoblooms in lakes with a relatively low macronutrient supply.

\section{Methods}

Study sites

For this study, 25 oligotrophic lakes from the Algoma Highlands in the Laurentian Great Lakes-St. Lawrence River Basin were selected based on minimal direct anthropogenic influences and public concern about the potential of cyanoblooms in the lakes (Fig. 1). The lakes are relatively shallow, thermally stratified during the warm summer months and are dimictic with major mixing events occurring during the spring snowmelt and autumn storms. These two major periods of hydrologic connectivity between land and lake represent important episodes of terrestrial nutrient input to lakes (Creed \& Band, 1998).

\section{Fieldwork}

Lakes were monitored throughout the growth season, with major sampling performed during the peak phytoplankton biomass period (September-October) in 2009, 2010 and 2011. This peak biomass period was identified based on a 2009 survey of these lakes from June to November (Fig. 2), which also matched well with reports by Winter et al. (2011) that cyanoblooms are occurring later in the growing season (October-November) compared with previous decades in this region of Ontario. At the lake, temperature, $\mathrm{pH}$, dissolved $\mathrm{O}_{2}$ and conductivity were measured at $1.0 \mathrm{~m}$ depth below the lake surface, and maximum lake depth $\left(Z_{\max }\right)$ and thermocline boundary depth $\left(Z_{\mathrm{tc}}\right)$ were measured using a YSI 600 QS multiparameter sonde with a YSI 650 MDS display (YSI Incorporated, Yellow Springs, OH, U.S.A.).

Surface water samples integrated to $1.0 \mathrm{~m}$ depth were collected in $500-\mathrm{mL}$ pre-rinsed polyethylene bottles near the centre of the lake, outside a phytoplankton bloom if present, and stored in the dark on ice in a cooler until 


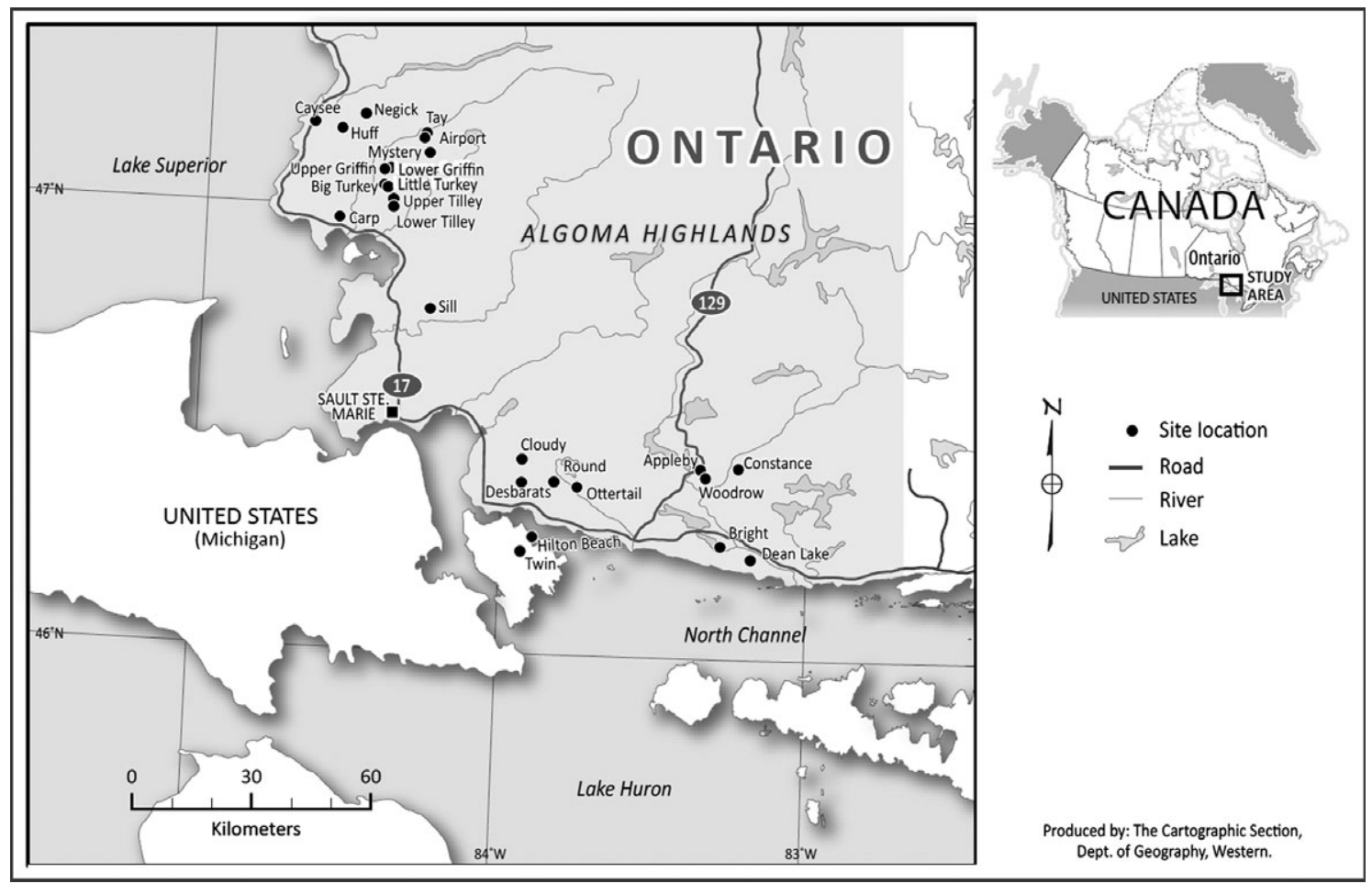

Fig. 1 Location of the surveyed oligotrophic lakes in the Algoma Highlands of central Ontario, Canada.

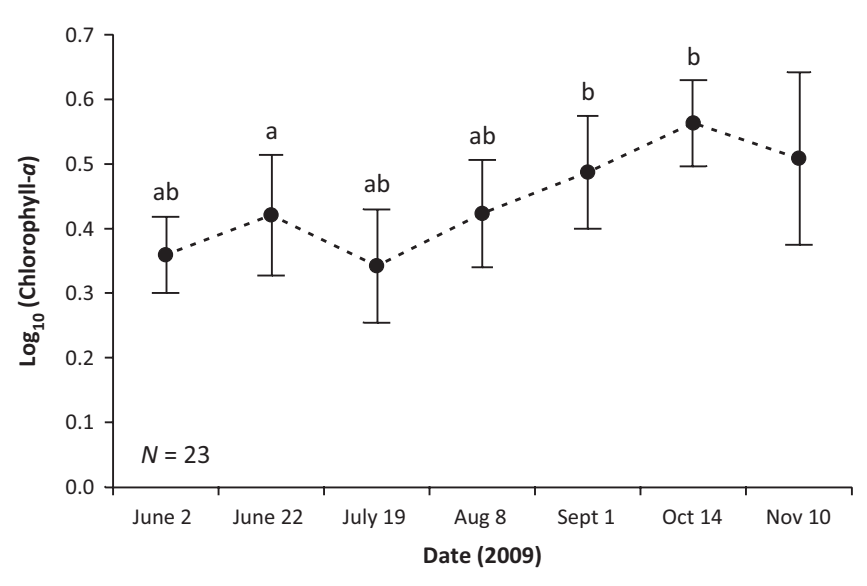

Fig. 2 Oligotrophic lake biomass (chl- $a, \pm \mathrm{SE}$ ) time series collected in 2009 to identify peak seasonal biomass. September and October biomass was significantly higher than that of early season (June) based on Friedman repeated measures ANOVA on ranks with Tukey's test (critical $\alpha=0.05$ ). Lettering denotes significant differences in chl- $a$ among sample periods. A decline in biomass was observed in November but was excluded from statistical analyses since not all lakes were accessible for sampling due to ice cover. Two lakes were excluded from the time series since early season sampling was not conducted, thus $N=23$.

return to the field laboratory. Median $Z_{\max }$ among the lakes is $5.3 \mathrm{~m}$ and median $Z_{\mathrm{tc}}$ is consistently $1.5 \mathrm{~m}$ among years $(25$ th $\%=0.81 \mathrm{~m}, 75$ th $\%=2.4 \mathrm{~m})$ so inte- grated water sampling to $1.0 \mathrm{~m}$ was chosen to standardise sampling among all lakes at a depth close enough to the thermocline boundary, and not directly through it, to capture phytoplankton populations and nutrients that would diffuse out of the hypolimnion. When visible blooms were present, the highest biomass was in areas where the phytoplankton material had accumulated due to winds. To avoid this bias, samples were made outside of, but adjacent to, the area of the visible phytoplankton bloom. Within the area of highest bloom density, some cells would be actively growing, some in stationary phase and some would be senescent. An additional pool of re-mineralised nutrients from biomass turnover would be expected in the centre of the bloom that would not be present on the bloom fringe where cells rely on ambient lake nutrients, which we measured and used for our correlative analyses. All lake water samples were processed within $12 \mathrm{~h}$ of collection and analysed immediately upon return to the laboratory.

\section{Phytoplankton}

A 500-mL subsample of lake water was filtered onto Whatman GF/F filters and analysed for chlorophyll- $a$ (chl-a) according to EPA Method 445.0 (Arar \& Collins, 1997). Chl- $a$ was extracted from filters using an acetone/ 
ultra-pure water solvent $(90: 10 \mathrm{v} / \mathrm{v})$ in $20-\mathrm{mL}$ scintillation vials and stored in the dark at $-20{ }^{\circ} \mathrm{C}$ for $20 \mathrm{~h}$. Samples were brought to room temperature in the dark and measured using a Turner 10-AU field fluorometer with a 680-nm emissions filter (Turner Designs, Sunnyvale, CA, U.S.A.).

A 3.5-mL subsample of unfiltered lake water was preserved with $1 \%$ buffered formaldehyde $(\mathrm{v} / \mathrm{v})$ in sterile Wheaton 5-mL cryule vials, and phytoplankton community composition was assessed using the BD FACSCalibur flow cytometer (BD Biosciences, Sparks, MD, U.S.A.) according to Marie et al. (1999). Water samples were vortexed to break apart colonies in best efforts to count single cells, but at low speeds and in pulses to avoid breaking cells. The vortexed water samples were then introduced to the flow cytometer where the fluorescent properties of cyanobacteria (orange fluorescence from phycobiliproteins) and eukaryotes (red fluorescence from chlorophyll) were detected for each cell in the sample. Cells were identified as cyanobacteria or eukaryote and total cell density was recorded. The proportion of cyanobacteria was enumerated by dividing the cell count for cyanobacteria by the total cell count (cyanobacteria + eukaryote) and multiplied by 100 to obtain a percentage of cyanobacteria in each sample. A 10-mL subsample of unfiltered lake water was used for taxonomic identification of phytoplankton genera with the Fluid Imaging FlowCAM (Fluid Imaging, Yarmouth, ME).

Flow cytometry using fluorescence was selected over traditional microscopy methods for phytoplankton community composition for several reasons: (i) samples preserve well and remain usable for this analysis for long periods of time while in the field; (ii) flow cytometry is very sensitive to both small and large cells, which is important in oligotrophic lakes where picocyanobacteria biomass may be significant and undifferentiated from debris in unfiltered samples; and (iii) there is assurance that small picocyanobacteria abundance is not underestimated relative to larger cyanobacterial cells.

\section{Nutrients}

A 90-mL subsample of unfiltered lake water was preserved with $10 \% \mathrm{H}_{2} \mathrm{SO}_{4}(\mathrm{v} / \mathrm{v})$ in screw-top borosilicate tubes. TP concentration was assessed by autoclaving for $30 \mathrm{~min}$ at $121{ }^{\circ} \mathrm{C}$ in sulphuric acid-persulphate medium to convert all $\mathrm{P}$ to orthophosphate and presented to the Technicon AutoAnalyzer (AAII) System (SEAL Analytical, Mequon, WI, U.S.A.) where the colorimetric reaction was measured on the inline spectrophotometer at $883 \mathrm{~nm}$.
A 300-mL subsample of lake water was filtered through a $0.45-\mu \mathrm{m}$ Pall Life Sciences (Mississauga, ON, Canada) polysulphonate membrane disc filter and analysed for nitrate and ammonium (colorimetry, analytical range is $10-1000 \mu \mathrm{g} \mathrm{L}^{-1}$ as $\mathrm{N}$ ) and metals (inductively coupled plasma spectrometry with a detection limit of $0.83 \mu \mathrm{g} \mathrm{L}^{-1}$ ) according to Ontario Ministry of the Environment \& Energy Standards Development Branch (1996). TN (unfiltered) and dissolved organic carbon (DOC, $0.45-\mu \mathrm{m}$ filtered) were assessed using a Shimadzu TOC- $\mathrm{V}_{\mathrm{CPH}}$ with TNM-1 and ASI-V auto-sampler with detection limits of $100 \mu \mathrm{g} \mathrm{L}^{-1}$ as $\mathrm{N}$ and $4.0 \mu \mathrm{g} \mathrm{L}^{-1}$ as DOC (Shimadzu, Kyoto, Japan). DON concentration was calculated by difference of TN-DIN $\left[\mathrm{NO}_{3}^{-}+\mathrm{NH}_{4}^{+}\right]$.

Ferric Fe concentration in lakes was modelled in Visual MINTEQ (v.3.0). Concentrations of the following nutrients and lake parameters were incorporated into the model: DOC, TP, nitrate, ammonium, sulphate, total dissolved $\mathrm{Fe}$ (TDFe), calcium, magnesium, chloride, $\mathrm{pH}$ and surface water temperature. The Stockholm Humic Model (SHM) of humic organic matter and metal complexation in Visual MINTEQ was used (Gustafsson, 2001). The SHM model was run with an assumed ratio of fulvic/ humic acids of $50 \%$ for lakes in the Algoma Highlands of central Ontario (Thurman \& Malcolm, 1981). The model output provided molar concentrations for all nutrients, metals and complexes upon which the modelled ferric $\mathrm{Fe}$ concentration was recorded for each lake.

\section{Statistical analysis}

A Friedman Repeated Measures ANOVA on ranks with Tukey's test (critical $\alpha=0.05$ ) was used to identify the peak biomass period in 2009 by investigating differences in biomass (chl-a) throughout the growing season (JuneNovember). A Kruskal-Wallis ANOVA on ranks with Dunn's test (critical $\alpha=0.05$ ) was used to investigate differences in total and dissolved nutrients, chl- $a$, phytoplankton densities (cyanobacteria, eukaryote and total) and $\mathrm{pH}$ during peak biomass between each of 3 years (2009, 2010 and 2011). Pearson correlations were used to investigate auto-correlation among lake nutrients (critical $\alpha=0.05)$. Exponential regression was used to investigate the relationship between thermocline boundary depth and cyanobacterial proportion.

A baseline threshold of cyanobacterial proportion (5\% cyanobacteria by cell density) that appeared to be common to all lakes was observed and selected so the specific factors leading to the growth of cyanobacteria above this threshold could be investigated. Lakes in all years combined were grouped into below baseline $(<5 \%$ 
cyanobacteria) and above baseline ( $>5 \%$ cyanobacteria). A Mann-Whitney $U$ rank sum test (critical $\alpha=0.05$ ) was used to investigate differences in total and dissolved nutrients, chl- $a$, phytoplankton densities (cyanobacteria, eukaryote and total), $\mathrm{pH}$ and surface water temperature between below-baseline and above-baseline lakes. All statistical measures were performed in SigmaPlot (v.11.0, SYSTAT Software, Chicago, IL, USA). Regression tree analysis was performed in R (v.2.15.3, Lucent Technologies, Murray Hill, NJ, USA) using the 'rpart' package to investigate the chemical determinants of chl-a, total phytoplankton density, eukaryote density and cyanobacterial proportion in lakes. Chemical parameters incorporated into the regression tree model included TP, TN, TN/TP, nitrate, ammonium, DIN, DIN/TP, DON, TDFe, modelled ferric Fe, sulphate, DOC, calcium, magnesium, chloride, $\mathrm{pH}$ and surface water temperature.

\section{Results}

\section{Community structure during peak phytoplankton biomass}

Lake phytoplankton community characteristics including total phytoplankton biomass (estimated by chl-a), total phytoplankton density and the density of cyanobacteria and eukaryotes that comprised total phytoplankton density in each of 3 years $(2009,2010$ and 2011) and for all years combined are presented in Table 1.
For all years combined, chl $a$ ranged from 0.5 to $54.7 \mu \mathrm{g} \mathrm{L}^{-1}$, eukaryote density ranged from $3.9 \times 10^{7}$ to $1.0 \times 10^{9}$ cells $\mathrm{L}^{-1}$, cyanobacterial density ranged from $4.8 \times 10^{5}$ to $4.6 \times 10^{7}$ cells $\mathrm{L}^{-1}$ and total phytoplankton density ranged from $4.6 \times 10^{7}$ to $1.0 \times 10^{9}$ cells L $^{-1}$ during peak phytoplankton biomass. Cyanobacterial density was found to be significantly higher in $2009\left(1.1 \times 10^{7}\right.$ cells $\left.\mathrm{L}^{-1}\right)$ versus $2011\left(2.1 \times 10^{6}\right.$ cells $\left.\mathrm{L}^{-1}\right)(P<0.05)$, and total phytoplankton density was found to be significantly higher in $2010\left(2.2 \times 10^{8}\right.$ cells $\left.\mathrm{L}^{-1}\right)$ versus 2011 $\left(1.6 \times 10^{8}\right.$ cells $\left.\mathrm{L}^{-1}\right)(P<0.05)$. No significant differences were found in chl- $a$ or eukaryote density among years.

Among all 3 years, cyanobacteria comprised a range of $<1-36 \%$ of the total phytoplankton density with the remaining density comprised of autotrophic chlorophyll-containing eukaryotic phytoplankton including chlorophytes, chrysophytes and diatoms. Lakes with the lowest total phytoplankton density had the highest cyanobacterial proportion, whereas lakes with relatively high total phytoplankton density had the lowest cyanobacterial proportion within phytoplankton communities (Fig. 3a). Lakes with the lowest chl- $a$ had the highest proportion of cyanobacteria, whereas lakes with the highest chl- $a$ had the lowest proportion of cyanobacteria (Fig. $3 b$ ). These trends were consistent throughout each of the 3 years of sampling during peak biomass. Cyanobacteria genera observed in above-baseline lakes included Microcystis spp., Anabaena spp. and Aphanizomenon spp.; no one individual genus was exclusively present in any lake at the

Table 1 Lake phytoplankton community characteristics: median, minimum, maximum and range for chl- $a$, eukaryotes, cyanobacteria and total phytoplankton density in each of 3 years $(2009,2010$ and 2011) and in all years combined

\begin{tabular}{|c|c|c|c|c|c|}
\hline Year & Statistic & $\begin{array}{l}\text { Chl- } a \\
\left(\mu \mathrm{g} \mathrm{L}^{-1}\right)\end{array}$ & $\begin{array}{l}\text { Eukaryotes } \\
\left(\text { cells L }{ }^{-1} \text { ) }\right.\end{array}$ & $\begin{array}{l}\text { Cyanobacteria } \\
\left(\text { cells } L^{-1}\right)\end{array}$ & $\begin{array}{l}\text { Total Density } \\
\text { (cells } L^{-1} \text { ) }\end{array}$ \\
\hline $\begin{array}{l}2009 \\
N=25\end{array}$ & $\begin{array}{l}\text { Med. } \\
\text { Min. } \\
\text { Max. } \\
\text { Range }\end{array}$ & $\begin{array}{r}3.1 \\
0.6 \\
54.7 \\
54.1\end{array}$ & $\begin{array}{l}1.8 \times 10^{8} \\
3.9 \times 10^{7} \\
5.1 \times 10^{8} \\
4.7 \times 10^{8}\end{array}$ & $\begin{array}{l}1.1 \times 10^{7 \mathbf{b}} \\
1.8 \times 10^{6} \\
3.9 \times 10^{7} \\
3.7 \times 10^{7}\end{array}$ & $\begin{array}{l}1.9 \times 10^{8 a b} \\
4.6 \times 10^{7} \\
5.2 \times 10^{8} \\
4.7 \times 10^{8}\end{array}$ \\
\hline $\begin{array}{l}2010 \\
N=25\end{array}$ & $\begin{array}{l}\text { Med. } \\
\text { Min. } \\
\text { Max. } \\
\text { Range }\end{array}$ & $\begin{array}{r}2.7 \\
0.5 \\
13.3 \\
12.8\end{array}$ & $\begin{array}{l}2.2 \times 10^{8} \\
5.8 \times 10^{7} \\
1.0 \times 10^{9} \\
9.4 \times 10^{8}\end{array}$ & $\begin{array}{l}5.1 \times 10^{6 \mathbf{a b}} \\
8.2 \times 10^{5} \\
2.9 \times 10^{7} \\
2.8 \times 10^{7}\end{array}$ & $\begin{array}{l}2.2 \times 10^{8 \mathbf{b}} \\
7.0 \times 10^{7} \\
1.0 \times 10^{9} \\
9.3 \times 10^{8}\end{array}$ \\
\hline $\begin{array}{l}2011 \\
N=25\end{array}$ & $\begin{array}{l}\text { Med. } \\
\text { Min. } \\
\text { Max. } \\
\text { Range }\end{array}$ & $\begin{array}{r}3.5 \\
1.1 \\
20.9 \\
19.8\end{array}$ & $\begin{array}{l}1.6 \times 10^{8} \\
5.1 \times 10^{7} \\
5.0 \times 10^{8} \\
4.5 \times 10^{8}\end{array}$ & $\begin{array}{l}2.1 \times 10^{6 a} \\
4.8 \times 10^{5} \\
4.6 \times 10^{7} \\
4.6 \times 10^{7}\end{array}$ & $\begin{array}{l}1.6 \times 10^{8 a} \\
5.7 \times 10^{7} \\
5.0 \times 10^{8} \\
4.4 \times 10^{8}\end{array}$ \\
\hline
\end{tabular}

Superscript letters in bold indicate significant differences between the 3 years based on Kruskal-Wallis ANOVA on ranks with Dunn's test (critical $\alpha=0.05)$. 

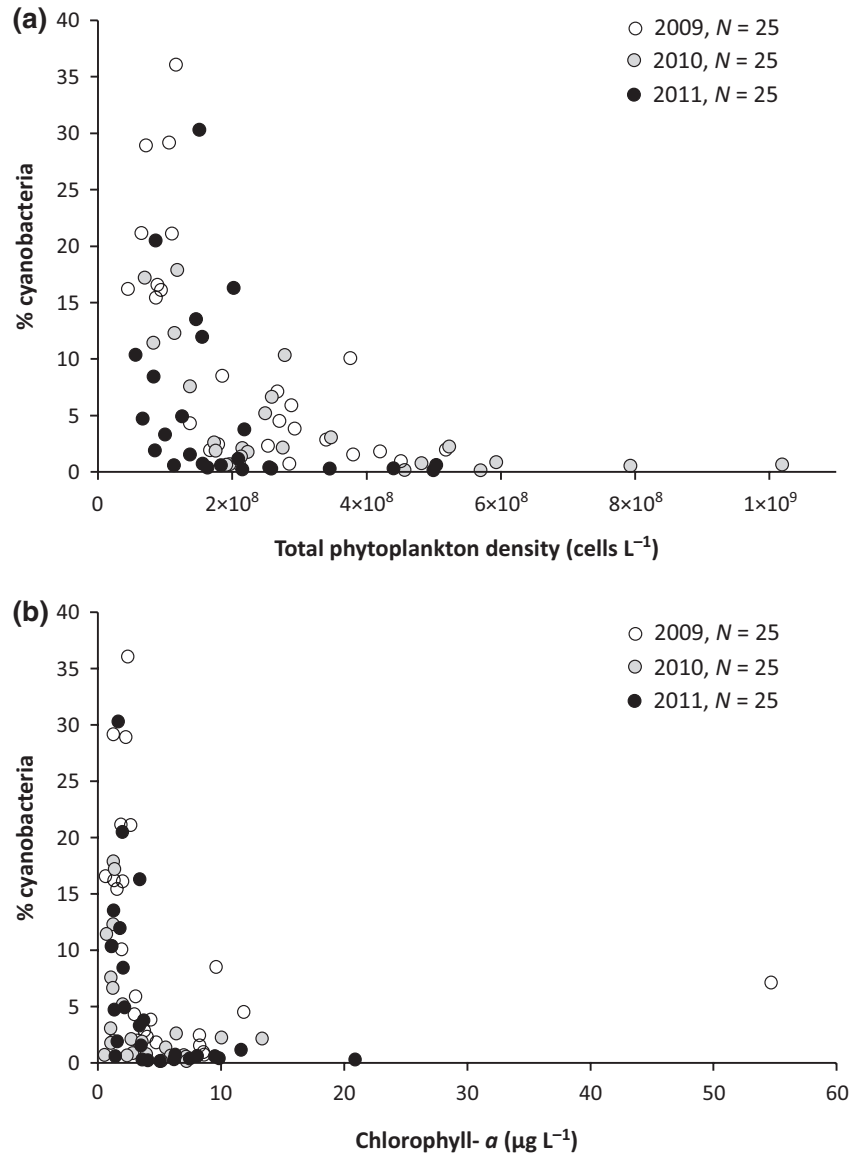

Fig. 3 Relationship between cyanobacterial proportion and (a) total phytoplankton density and (b) chl- $a$ in the oligotrophic lakes during the peak biomass in 2009-2011.

time of sampling. Picocyanobacteria were more prominent in the below-baseline lakes with an absence of the colonial and filamentous species.

\section{Nutrient ranges, ratios and measures of limitation}

The median thermocline boundary depth $\left(Z_{t c}\right)$ was $1.5 \mathrm{~m}$, and the median maximum depth $\left(Z_{\max }\right)$ was $5.3 \mathrm{~m}$ among all lakes. $Z_{\mathrm{tc}}$ was found to exhibit a significant exponential decay trend when correlated to lakes with above-baseline cyanobacteria $\left(r^{2}=0.81, P<0.05\right)$, while no significant relationship was found in the below-baseline lakes (Fig. 4).

According to the Pearson correlation matrix (Table 2), modelled ferric $\mathrm{Fe}$ was not auto-correlated with any other lake nutrients. Lake chemical characteristics in each of 3 years (2009, 2010 and 2011) and for all years combined are presented in Table 3. For all years combined, TP in the lakes ranged from 2.2 to $59.7 \mu \mathrm{g} \mathrm{L}^{-1}$. Soluble reactive P (SRP) was not detected in

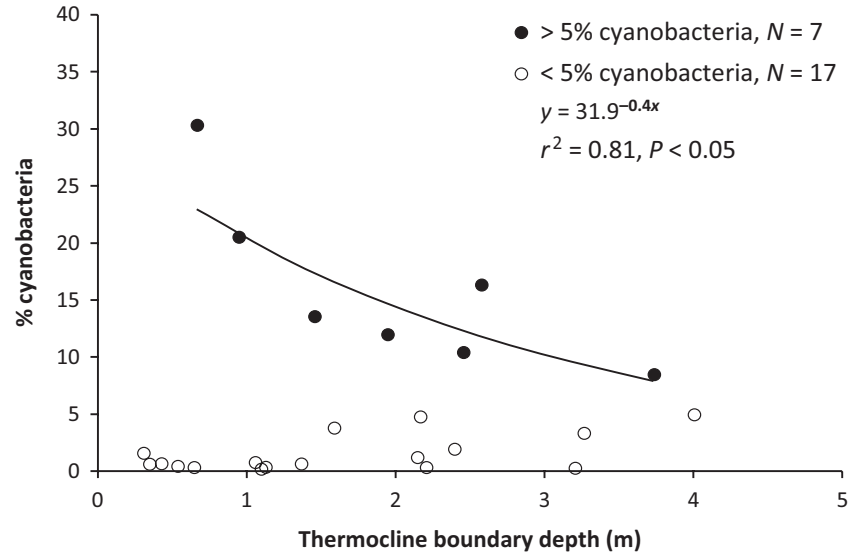

Fig. 4 Relationship between cyanobacterial proportion and thermocline boundary depth $(\mathrm{m})$ in the oligotrophic lakes. Lakes with cyanobacterial communities greater than $5 \%$ exhibited an exponential decay trend with increasing thermocline boundary depth.

any lake samples as concentrations were below method detection limit $\left(<0.2 \mu \mathrm{g} \mathrm{L}^{-1}\right)$ at the time of sampling. For all years combined, TP determined total phytoplankton biomass (chl- $a)$ in the lakes $\left(r^{2}=0.54, P<0.001\right)$. TP was found to be significantly higher in $2009\left(13.9 \mu \mathrm{g} \mathrm{L}^{-1}\right)$ versus $2011\left(8.9 \mu \mathrm{g} \mathrm{L}^{-1}\right)(P<0.05)$. Lakes with the lowest TP had the highest cyanobacterial proportion, whereas lakes with the highest TP had the lowest cyanobacterial proportion (Fig. 5). For all years combined, TN in the lakes ranged from $c$. 200 to $2400 \mu \mathrm{g} \mathrm{L}^{-1}$; no significant differences were found in TN among years, and no significant relationship was found between TN and cyanobacterial proportion. The majority of TN was organic $\mathrm{N}(95 \%)$, with nitrate being the primary form of inorganic N (5\%). Nitrate was significantly higher in 2009 $\left(13.3 \mu \mathrm{g} \mathrm{L}^{-1}\right)$ versus $2010\left(1.7 \mu \mathrm{g} \mathrm{L}^{-1}\right)(P<0.05)$, while ammonium was significantly different among all 3 years in $2009\left(29.0 \mu \mathrm{g} \mathrm{L}^{-1}\right)$ versus $2010\left(3.0 \mu \mathrm{g} \mathrm{L}^{-1}\right)$ versus $2011\left(8.0 \mu \mathrm{g} \mathrm{L}^{-1}\right.$ ) (all $P<0.05$ ). DIN was significantly higher in $2009\left(46.7 \mu \mathrm{g} \mathrm{L}^{-1}\right)$ versus $2010\left(7.7 \mu \mathrm{g} \mathrm{L}^{-1}\right)$ $(P<0.05)$ and versus $2011\left(13.9 \mu \mathrm{g} \mathrm{L}^{-1}\right)(P<0.05)$. No significant difference was found in DON among years.

For all years combined, the molar ratio of TN/TP in the lakes ranged from 19:1 to 406:1. TN/TP was significantly higher in 2011 (102:1 molar) versus 2009 (64:1 molar $(P<0.05)$. The highest cyanobacterial proportion occurred at a TN/TP molar ratio of $66: 1$ (36\% cyanobacteria), with high variability in cyanobacterial proportion at TN/TP molar ratios greater than 66:1 (Fig. 6a). For all years combined, the molar ratio of DIN/TP in the lakes ranged from $0.3: 1$ to 193:1. DIN/TP was significantly higher in 2009 (6.1:1 molar) versus 2010 (1.1:1 molar) $(P<0.05)$. The highest cyanobacterial proportion among 
Table 2 Pearson correlation matrix for lake nutrients (critical $\alpha=0.05$ ). Modelled ferric Fe was the only nutrient not auto-correlated with any other nutrient in the lakes. Data are presented as Pearson $R$ (sample N). Positive Pearson $R$ indicates a positive linear relationship between nutrients, and a negative Pearson $R$ indicates a negative linear relationship

\begin{tabular}{|c|c|c|c|c|c|c|c|c|c|c|}
\hline & $\mathrm{TP}$ & $\mathrm{TN}$ & $\mathrm{TN} / \mathrm{TP}$ & $\mathrm{NO}_{3}^{-}$ & $\mathrm{NH}_{4}^{+}$ & DON & DIN & DIN/TP & TDFe & $\mathrm{Fe}^{3+}$ \\
\hline $\mathrm{TP}$ & & $0.15(75)$ & $-0.53(74)$ & $-0.22(74)$ & $0.15(74)$ & $0.19(74)$ & $-0.17(74)$ & $-0.34(74)$ & $0.24(75)$ & $0.03(75)$ \\
\hline TN/TP & & & & $0.26(74)$ & $-0.09(74)$ & $0.42(74)$ & $0.22(74)$ & $0.52(74)$ & $-0.24(74)$ & $-0.02(74)$ \\
\hline $\mathrm{NO}_{3}^{-}$ & & & & & $0.33(74)$ & $-0.30(74)$ & $0.98(74)$ & $0.85(74)$ & $-0.24(74)$ & $-0.06(74)$ \\
\hline $\mathrm{NH}_{4}^{+}$ & & & & & & $0.06(74)$ & $0.50(74)$ & $0.19(74)$ & $0.14(74)$ & $-0.07(74)$ \\
\hline DIN/TP & & & & & & & & & $-0.22(74)$ & $-0.06(74)$ \\
\hline TDFe & & & & & & & & & & $0.06(75)$ \\
\hline
\end{tabular}

Pearson $R$ values in bold indicate a statistically significant relationship between lake nutrients $(P<0.05)$ and italicised Pearson $R$ indicates no significant relationship.

Table 3 Lake chemical characteristics - median, minimum, maximum and range in each of 3 years (2009, 2010 and 2011) and in all years combined

\begin{tabular}{|c|c|c|c|c|c|c|c|c|c|c|c|c|}
\hline Year & Statistic & $\mathrm{pH}$ & $\begin{array}{l}\text { DOC } \\
\left(\mu \mathrm{g} \mathrm{L}^{-1}\right)\end{array}$ & $\begin{array}{l}\text { TDFe } \\
\left(\mu \mathrm{g} \mathrm{L}^{-1}\right)\end{array}$ & $\begin{array}{l}\mathrm{TP} \\
\left(\mu \mathrm{g} \mathrm{L}^{-1}\right)\end{array}$ & $\begin{array}{l}\mathrm{TN} \\
\left(\mu \mathrm{g} \mathrm{L}^{-1}\right)\end{array}$ & $\begin{array}{l}\mathrm{NO}_{3}^{-} \\
\left(\mu \mathrm{g} \mathrm{L}^{-1}\right)\end{array}$ & $\begin{array}{l}\mathrm{NH}_{4}^{+} \\
\left(\mu \mathrm{g} \mathrm{L}^{-1}\right)\end{array}$ & $\begin{array}{l}\mathrm{DIN} \\
\left(\mu \mathrm{g} \mathrm{L}^{-1}\right)\end{array}$ & $\begin{array}{l}\mathrm{DON} \\
\left(\mu \mathrm{g} \mathrm{L}^{-1}\right)\end{array}$ & $\begin{array}{l}\mathrm{TN} / \mathrm{TP} \\
\text { (molar) }\end{array}$ & $\begin{array}{l}\text { DIN/TP } \\
\text { (molar) }\end{array}$ \\
\hline \multirow{3}{*}{$\begin{array}{l}2009 \\
N=25\end{array}$} & Med. & $7.9^{c}$ & $5610.5^{\mathbf{b}}$ & 15.7 & $13.9^{\mathbf{b}}$ & 421.7 & $13.3^{\mathbf{b}}$ & $29.0^{c}$ & $46.7^{\mathbf{b}}$ & 297.9 & $63.8^{\mathrm{a}}$ & $6.1^{\mathrm{b}}$ \\
\hline & Max. & 9.1 & 18578.0 & 267.3 & 59.7 & 2415.5 & 230.1 & 61.7 & 248.3 & 2371.4 & 375.8 & 65.8 \\
\hline & Range & 3.7 & 15953.8 & 264.0 & 51.7 & 2198.7 & 220.1 & 54.0 & 227.6 & 2197.6 & 353.0 & 64.5 \\
\hline \multirow{3}{*}{$\begin{array}{l}2010 \\
N=25\end{array}$} & Med. & $6.9^{a}$ & $5105.0^{\mathbf{a b}}$ & 12.0 & $10.4^{\mathbf{a b}}$ & 338.1 & $1.7^{\mathrm{a}}$ & $3.0^{\mathrm{a}}$ & $7.7^{\mathrm{a}}$ & 303.4 & $72.3^{\mathbf{a b}}$ & $1.9^{\mathbf{a}}$ \\
\hline & Max. & 7.8 & 12246.2 & 136.8 & 39.4 & 579.4 & 179.9 & 8.0 & 182.8 & 571.5 & 178.2 & 96.4 \\
\hline & Range & 2.0 & 11594.6 & 133.9 & 35.8 & 367.6 & 178.2 & 5.0 & 178.1 & 428.6 & 158.8 & 96.1 \\
\hline \multirow{4}{*}{$\begin{array}{l}2011 \\
N=25\end{array}$} & Med. & $7.4^{\mathrm{b}}$ & $3076.1^{a}$ & 10.0 & $8.9^{\mathrm{a}}$ & 364.8 & $4.0^{\mathrm{ab}}$ & $8.0^{\mathbf{b}}$ & $13.9^{\mathrm{a}}$ & 332.7 & $102.3^{\mathbf{b}}$ & $2.7^{\mathrm{ab}}$ \\
\hline & Min. & 6.1 & 449.8 & 6.1 & 2.2 & 230.1 & 1.7 & 3.0 & 4.7 & 19.6 & 20.0 & 0.3 \\
\hline & Max. & 8.0 & 19588.4 & 150.0 & 37.4 & 547.0 & 311.9 & 64.0 & 375.8 & 529.7 & 406.4 & 193.2 \\
\hline & Range & 1.9 & 19138.6 & 143.9 & 35.2 & 316.9 & 310.2 & 61.0 & 371.1 & 510.1 & 386.4 & 192.9 \\
\hline $\begin{array}{l}\text { All Years } \\
N=75\end{array}$ & Range & 3.7 & 19138.6 & 264.4 & 57.5 & 2203.7 & 310.2 & 61.0 & 371.1 & 2351.8 & 387.0 & 192.9 \\
\hline
\end{tabular}

Superscript letters in bold indicate significant differences between the 3 years based on Kruskal-Wallis ANOVA on ranks with Dunn's test (critical $\alpha=0.05$ ).

all lake samples was observed at a DIN/TP molar ratio of 8:1 (36\% cyanobacteria) (Fig. 6b).

Additionally, $\mathrm{pH}$ was significantly different between all 3 years in 2009 (7.9) versus 2010 (6.9) versus 2011 (7.4) (all $P<0.05$ ). DOC was significantly higher in 2009 $\left(5610 \mu \mathrm{g} \mathrm{L}^{-1}\right)$ versus $2011\left(3076 \mu \mathrm{g} \mathrm{L}^{-1}\right)(P<0.05)$. No significant difference was found in TDFe between years.

\section{Nutrients and phytoplankton in lakes above and below baseline}

For all years combined, modelled ferric $\mathrm{Fe}$ in the lakes ranged from $1.0 \times 10^{-25}$ to $1.0 \times 10^{-13} \mathrm{M}$. The highest cyanobacterial proportion occurred at a modelled ferric Fe concentration of $1.0 \times 10^{-21} \mathrm{M}$ ( $36 \%$ cyanobacteria). All lakes with above-baseline cyanobacteria corresponded to modelled ferric Fe concentrations $<1.0 \times 10^{-19} \mathrm{M}$ (Fig. 7)

Chemical and phytoplankton characteristics in lakes with above- and below-baseline cyanobacteria are presented in Table 4. Lakes with above-baseline cyanobacteria had significantly higher cyanobacterial density $\left(1.6 \times 10^{7}\right.$ versus $3.3 \times 10^{6}$ cells $\left.\mathrm{L}^{-1}\right)$, lower chl- $a(1.7$ versus $\left.4.8 \mu \mathrm{g} \mathrm{L}^{-1}\right)$, lower eukaryote density $\left(9.5 \times 10^{7}\right.$ versus $2.5 \times 10^{8}$ cells $\mathrm{L}^{-1}$ ) and lower total phytoplankton density $\left(1.1 \times 10^{8}\right.$ versus $2.2 \times 10^{8}$ cells $\left.\mathrm{L}^{-1}\right)$ compared with lakes with below-baseline cyanobacteria (all $P<0.05$ ).

Lakes with above-baseline cyanobacteria had significantly higher surface temperature (17.4 versus $16.3{ }^{\circ} \mathrm{C}$ ), 


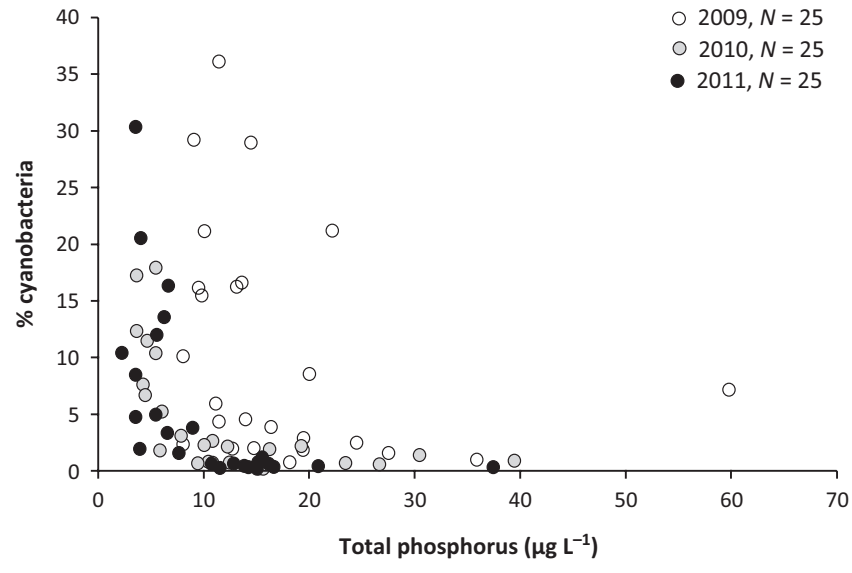

Fig. 5 Relationship between cyanobacterial proportion and TP in the oligotrophic lakes during peak biomass.

nitrate (18.2 versus $4.9 \mu \mathrm{g} \mathrm{L}^{-1}$ ), TN/TP (104.7:1 versus 63.1:1 molar), DIN (49.0 versus $15.5 \mu \mathrm{g} \mathrm{L}^{-1}$ ) and DIN/TP (10.2:1 versus 2.3:1 molar). Other factors such as TDFe (6.2 versus $\left.30.2 \mu \mathrm{g} \mathrm{L}^{-1}\right)$, TP $\left(6.5\right.$ versus $\left.14.1 \mu \mathrm{g} \mathrm{L}^{-1}\right)$, DON (245.5 versus $354.8 \mu \mathrm{g} \mathrm{L}^{-1}$ ) and DOC (3,981.1 versus $5,370.8 \mu \mathrm{g} \mathrm{L}^{-1}$ ) were significantly lower compared with lakes with below-baseline cyanobacteria (all $P<0.05$ ). No significant difference was found in TN between lakes with above- and below-baseline cyanobacteria.

\section{Combinatorial nutrient determinants of phytoplankton community structure in lakes}

Regression tree analysis of the lake chemical and biological data indicated that there were complex combinatorial determinants that separated the eukaryotic phytoplankton from the cyanobacteria. TP, with additional influence of DON and DOC, was the prime environmental factor that determined chl- $a$ in these oligotrophic lakes (Fig. 8a). In contrast, the ratio of TP to nitrogen (both TN and DIN) determined the phytoplankton density (Fig. 8b). Differentiating between the eukaryotic and prokaryotic phototrophic plankton required two independent sets of environmental parameters. The eukaryotic phytoplankton density was positively correlated to the ratio of TN to TP (Fig. 8c). In contrast, distinctly independent parameters of low modelled ferric $\mathrm{Fe}$ and available nitrogen correlated most strongly with the cyanobacterial proportion (Fig. 8d).

\section{Discussion}

The primary objective of this study was to determine whether $\mathrm{P}$ or $\mathrm{N}$ limits cyanobacterial growth and what
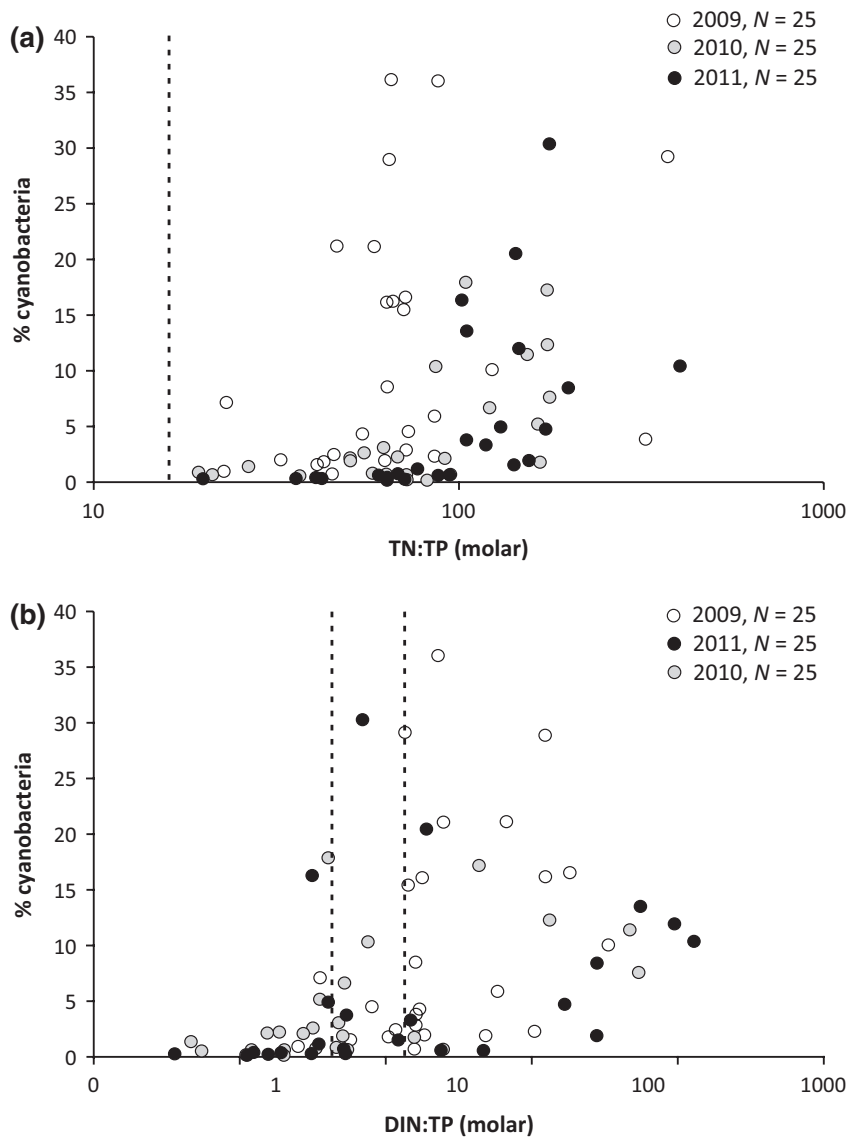

Fig. 6 (a) Relationship between cyanobacterial proportion and $\mathrm{TN} / \mathrm{TP}$ (molar ratio) in the oligotrophic lakes during peak biomass. Dashed vertical line represents the threshold for N-limitation (TN/TP<16:1) and P-limitation (TN/TP >16:1) according to the Redfield nutrient limitation principles on biomass (Redfield et al., 1963). (b) Relationship between cyanobacterial proportion and DIN/TP (molar ratio) in the oligotrophic lakes during the peak biomass. Dashed vertical lines represent the threshold for $\mathrm{N}$-limitation (DIN/TP <2) and P-limitation (DIN/TP >5) and lakes that fall between these lines represent co-limited lakes for DIN and TP according to the Ptacnik et al. (2010) nutrient limitation principles. X-axes are $\log _{10}$-scaled.

role ferric Fe may have in alleviating P- or N-limitation on cyanobacterial biomass. We found that the influences of P- and N-limitation are minimal and that cyanobacteria are most competitive in low $\mathrm{Fe}$ environments.

\section{Community structure during peak phytoplankton biomass}

With the highest proportion of cyanobacteria found to be $36 \%$ among 3 years of sampling, none of the oligotrophic lakes were considered to be experiencing cyanoblooms during peak biomass period, other than visible biomass accumulation due to wind. Thus, this study focused on those nutrient controls that result in shifts 
from picocyanobacteria to more transitionary cyanobacterial communities.

We investigated whether patterns existed among lakes with respect to total phytoplankton density and cyanobacterial proportion in oligotrophic lakes. The observation that highest cyanobacterial proportion occurred when total phytoplankton density and chl- $a$ were lowest

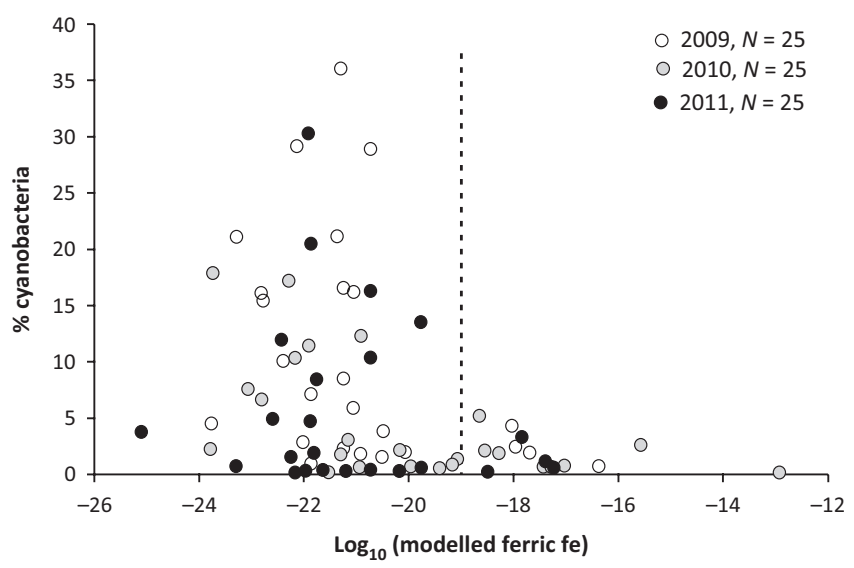

Fig. 7 Relationship between cyanobacterial proportion and modelled ferric Fe in the oligotrophic lakes during peak biomass. The highest cyanobacterial proportion was observed at [modelled ferric $\mathrm{Fe}]<1.0 \times 10^{-19} \mathrm{M}$. The dashed vertical line represents a threshold in ferric Fe where cyanobacteria have shown to be competitive for Fe when limiting in laboratory experiments (Kerry et al., 1988). in lakes is consistent with the findings of Watson, McCauley and Downing (1997) that phytoplankton biomass and species diversity are low in temperate oligotrophic lakes and cyanobacteria can dominate the picophytoplankton community, but with nutrient enrichment, taxonomic diversity increases. Picocyanobacteria dominated the oligotrophic lakes when overall phytoplankton biomass was low, but in higher biomass lakes with higher nutrient levels, the community was comprised of transitionary cyanobacteria (Microcystis spp., Anabaena spp. and Aphanizomenon spp.) with more taxonomic diversity. None of the lakes achieved high biomass, mono-specific communities, which would constitute a cyanobloom.

\section{Nutrient ranges, ratios and inferences of limitation}

All lakes with cyanobacterial proportions above the baseline ( $>5 \%$ cyanobacteria) were significantly and negatively correlated to increasing $Z_{\mathrm{tc}}$, suggesting that cyanobacteria in these surface water communities may use buoyancy control to exploit diffusing hypolimnetic nutrient sources, although no vertical depth samples were available to confirm this. The negative trend observed may indicate that with a deeper $Z_{\mathrm{tc}}$, it is more difficult to migrate vertically and obtain hypolimnetic nutrients to satisfy metabolic demand. Genera observed

Table 4 Lake chemical (above) and phytoplankton (below) characteristics: median, minimum, maximum and range in lakes with less than $5 \%$ baseline cyanobacteria versus lakes with greater than $5 \%$ baseline cyanobacteria

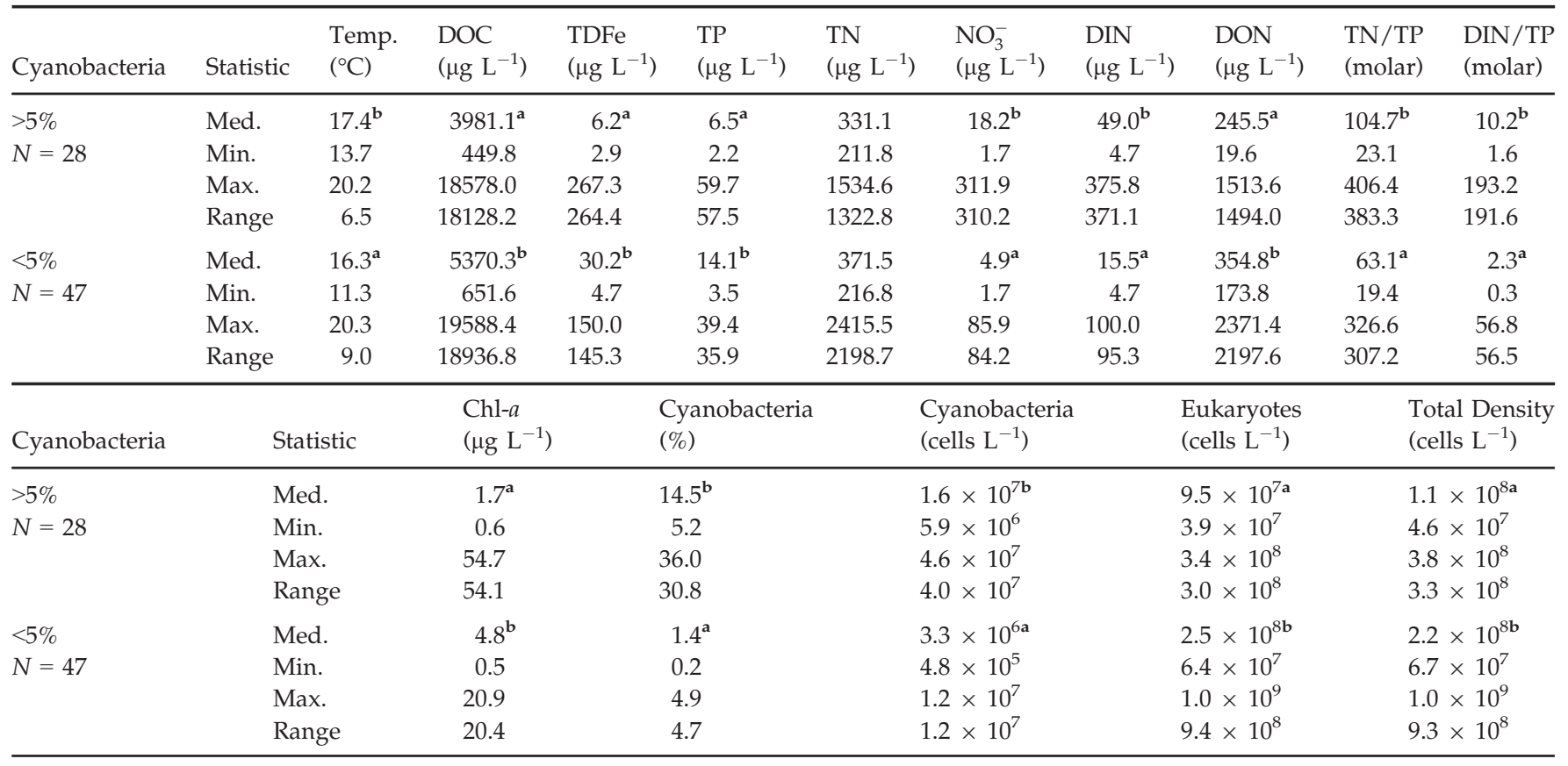

Superscript letters in bold indicate significant differences between above and below-baseline lakes based on Mann-Whitney $U$ rank sum test (critical $\alpha=0.05)$. 


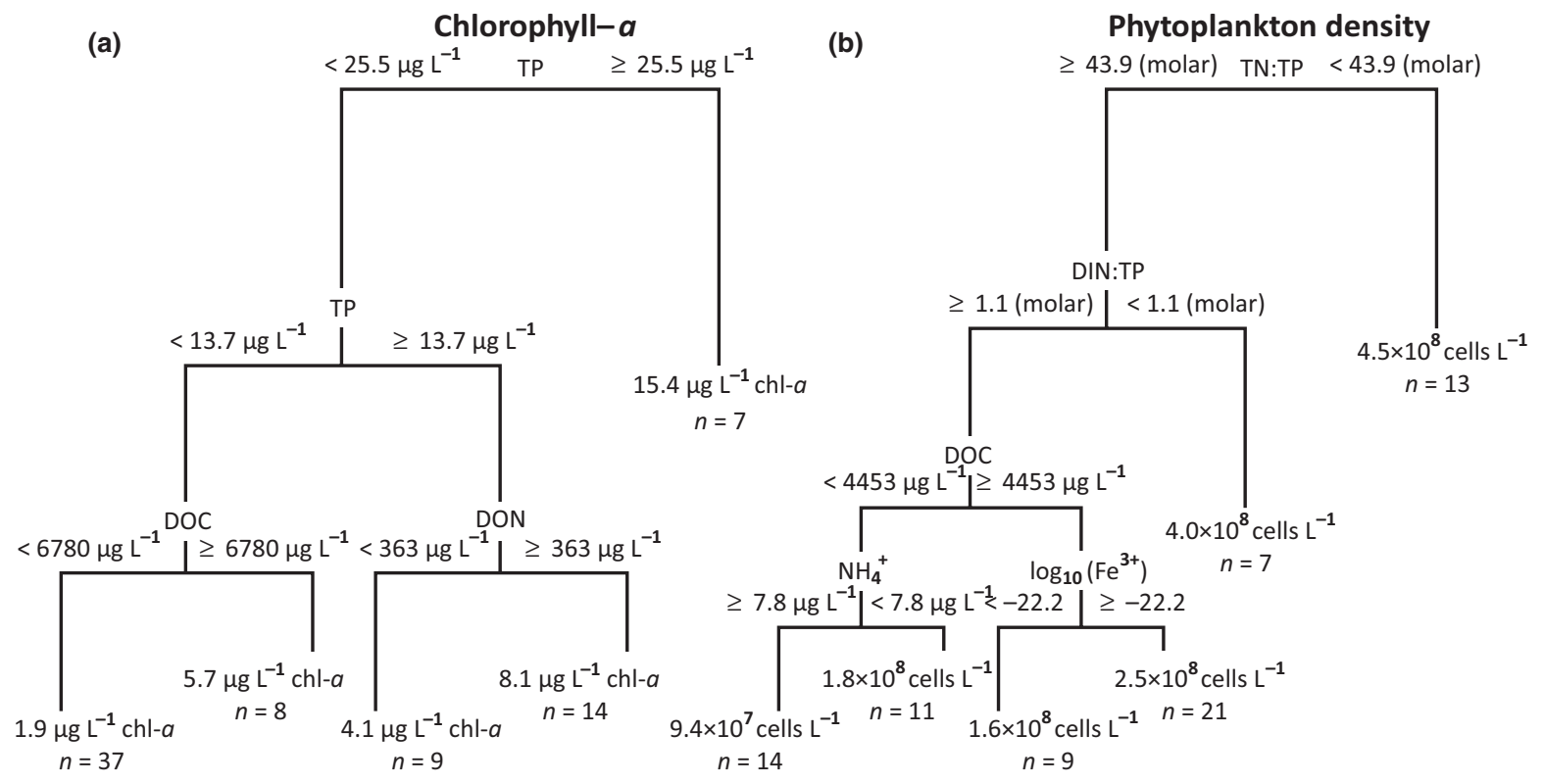

(c)

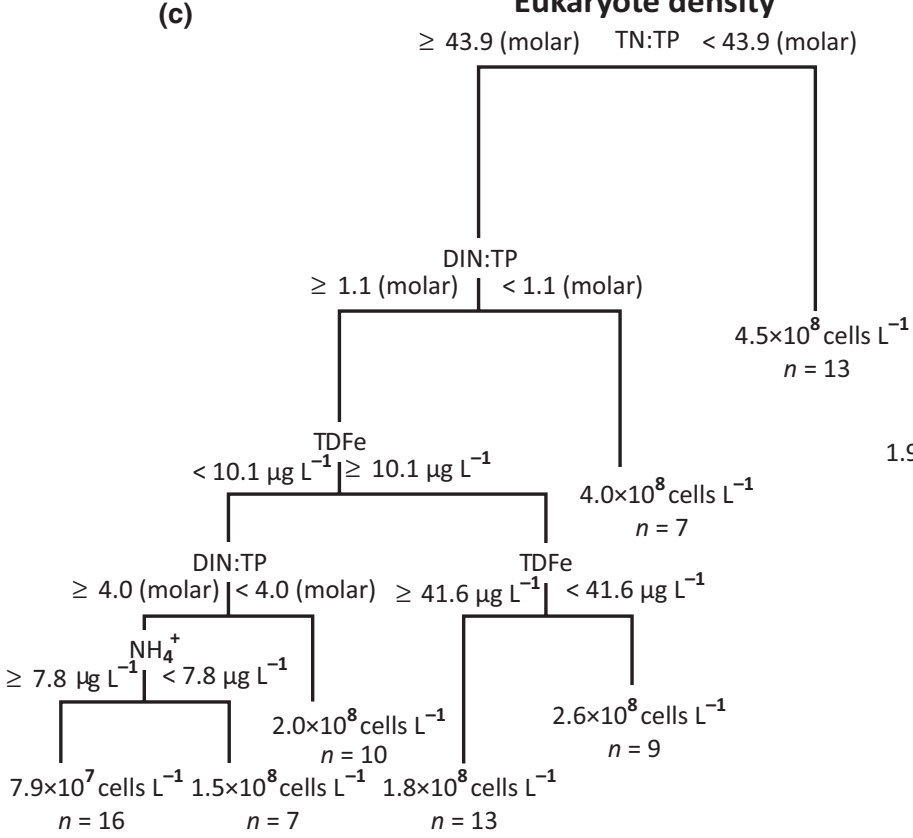

(d)

\section{Proportion of cyanobacteria} $\geq 9.9 \mu \mathrm{g} \mathrm{L}^{-1}$ TDFe $\quad<9.9 \mu \mathrm{g} \mathrm{L}$

Fig. 8 Regression tree depicting the chemical determinants of (a) chl-a, (b) total phytoplankton density, (c) eukaryotic phytoplankton and (d) cyanobacterial proportion in the oligotrophic lakes during peak biomass.

in the above-baseline lakes, including Microcystis spp. (Mur et al., 1999) and Anabaena spp. (Kinsman, Ibelings \& Walsby, 1991), have been shown to utilise the buoyancy control strategy; this may enable them to obtain internally loaded nutrients from the hypolimnion, which are an important source of $\mathrm{P}$ and $\mathrm{Fe}$ in other shallow Canadian freshwater lakes (Petticrew \& Arocena, 2001).

The observation of highest cyanobacterial proportion at lowest TP in lakes may be attributed to cyanobacteria having the ability of luxury $\mathrm{P}$ uptake, high internal cellular storage capacity of $\mathrm{P}$ relative to the other phytoplankton (Mur et al., 1999) and high P transport affinity at low P concentrations (Molot \& Brown, 1986). When $\mathrm{P}$ concentration is low, cyanobacteria may outcompete other phytoplankton groups with lower $\mathrm{P}$ transport affinity and an inferior internal cellular storage capacity resulting in a higher proportion of cyanobacteria within the phytoplankton community. 
According to Redfield ratio stoichiometry (Redfield, Ketchum \& Richards, 1963), phytoplankton biomass in the lakes may have been P-limited at the time of sampling with TN/TP $>16: 1$ as a molar ratio. Other studies have found that DIN/TP predicts phytoplankton biomass better than TN and TP concentrations or TN/TP because DIN/TP provides a more representative indication of bioavailable inorganic $\mathrm{N}$ where $\mathrm{N}$-limitation may occur at DIN/TP $<2: 1$ and P-limitation may occur at DIN/TP $>5: 1$ as molar ratios (Ptacnik, Andersen \& Tamminen, 2010). Since about $95 \%$ of $\mathrm{TN}$ in the lakes was DON, which is a fraction of $\mathrm{N}$ in the total $\mathrm{N}$ pool that is not immediately bioavailable to phytoplankton, and SRP was undetectable, investigation using DIN/TP was warranted. The highest cyanobacterial proportion $(36 \%)$ across a gradient of DIN/TP in the lakes was at DIN/TP $=8: 1$ as a molar ratio, a potentially P-limited condition. By DIN/TP limitation definitions, biomass may have been P-limited in $47 \%$ of lakes, DIN-limited in $26 \%$ of lakes and co-limited by DIN and TP in $27 \%$ of lakes at the time of sampling.

Both metrics presented here (TN/TP and DIN/TP) suggest different nutrient limitation conditions on biomass in the same lakes. Schindler (2012) discussed common errors in the interpretation of ecosystem processes and indicators, one of which is the incorrect assumption that ratios of total, suspended or dissolved nutrients are reliable indicators of nutrient limitation. Although we agree that DIN/TP may be a more reliable indicator of nutrient limitation of biomass in the lakes than TN/TP, we also agree with Schindler (2012) that additional factors must be considered when evaluating nutrient limitation of biomass in lakes. We argue that Fe plays an important role in nutrient limitation since $\mathrm{Fe}$ is directly involved in phytoplankton macronutrient $\mathrm{P}$ and $\mathrm{N}$ use efficiency.

\section{Nutrients and phytoplankton in lakes above and below baseline}

We hypothesised that cyanobacterial growth would be highest in a range of modelled ferric Fe not readily accessible to eukaryotic phytoplankton $\left(<1.0 \times 10^{-19} \mathrm{M}\right)$. Naturally occurring concentrations of ferric $\mathrm{Fe}$ are expected to range from $1.0 \times 10^{-17}$ to $1.0 \times 10^{-21} \mathrm{M}$ in neutral aquatic systems (Schneider \& Schwyn, 1987). We found that while some of the lakes fell within this expected range of ferric $\mathrm{Fe}$, the majority of lakes had far lower concentrations of modelled ferric Fe that gave rise to the highest cyanobacterial proportions, $<1.0 \times 10^{-19} \mathrm{M}$. The ability of cyanobacteria to thrive and increase relative to the other phytoplankton in these lakes with low modelled ferric Fe could be due to the siderophore-based
Fe acquisition strategy used by some cyanobacteria providing a competitive advantage during $\mathrm{Fe}$ stress (Neilands, 1995). Studies of siderophores in oligotrophic lakes within the Laurentian Great Lakes-St. Lawrence River Basin are lacking, with only one record documenting the presence and utilisation of hydroxamate-type siderophores by Anabaena flos-aquae in the Bay of Quinte, a eutrophic bay on the northern shore of Lake Ontario (Murphy et al., 1976).

Kerry et al. (1988) found that siderophore production by cyanobacteria (Anacystis nidulans) was initiated at a ferric Fe concentration of $1.0 \times 10^{-19} \mathrm{M}$, which matches well with the modelled ferric Fe concentrations in the oligotrophic lakes with the highest cyanobacterial proportions. This suggests that cyanobacteria may be utilising siderophores as a mechanism to obtain ferric $\mathrm{Fe}$, providing cyanobacteria with a competitive advantage in this range of ferric Fe over other phytoplankton that do not have the capacity to produce siderophores. Oligotrophic lakes with ferric $\mathrm{Fe}$ concentrations $>1.0 \times 10^{-20} \mathrm{M}$ may provide sufficient ferric Fe to promote and sustain growth of all phytoplankton, thus eliminating any competitive advantage by cyanobacteria for Fe acquisition. Cyanobacterial genera known to have the capacity to produce and utilise siderophores and that were observed in the oligotrophic lakes included Anabaena spp. (Wilhelm \& Trick, 1994) and Microcystis spp. (Murphy et al., 1976). Although consensus pertaining to the minimum Fe requirement to promote and sustain cyanobacterial growth is lacking, the decline in cyanobacterial proportion observed at modelled ferric $\mathrm{Fe}$ concentrations $<1.0 \times 10^{-22} \mathrm{M}$ may represent the minimum ferric Fe concentration required to support cyanobacterial growth in these oligotrophic lakes.

Ferric Fe bioavailability for $\mathrm{N}$-assimilation and $\mathrm{N}_{2}^{-}$ fixation may be an important regulator of cyanoblooms in oligotrophic lakes. We suspect that the limited amount of modelled ferric Fe in lakes above the baseline may be accessible exclusively to cyanobacteria via the siderophore-based Fe acquisition strategy. By scavenging and thus dictating the bioavailability of ferric Fe to other phytoplankton in surface waters, cyanobacteria have the capacity to be competitive for and assimilate DIN or fix $\mathrm{N}_{2}$ when nitrate supplies are low, while increasing in proportion relative to eukaryotic phytoplankton.

\section{Combinatorial nutrient determinants of phytoplankton community structure in lakes}

The regression tree evaluation clearly documents that the factor primarily correlating to the rise of the transitionary 
colonial or filamentous cyanobacteria is the ability to thrive in low Fe environments, regardless of the macronutrient composition. The dichotomy between the factors regulating the eukaryote cells and the cyanobacteria shows almost no overlap. As observed in all above-baseline oligotrophic lakes where TDFe was low and DIN was high, cyanobacteria may have used siderophores to scavenge $\mathrm{Fe}$ required for $\mathrm{N}$-assimilation, restricting $\mathrm{Fe}$ access, and thus $\mathrm{N}$ access, to eukaryote phytoplankton. This leads us to conclude that there is very little direct competition for nutrients, but rather each group exists in a very specific ecological homeostasis.

A possible, but presently untested, scenario is that the initial state, physiological health potential, of the community (eukaryotic phytoplankton versus transitionary cyanobacteria) at the time of addition of internally or externally derived phosphorus would lead one population to out-grow the other, leading to predominance (bloom) of that one ecotype. Given the rise in cyanobacteria in oligotrophic lakes, future research is needed on landscape controls on the mobilisation of Fe to lakes and/or lake controls on the fate of $\mathrm{Fe}$ to complement recent research on changing $P$ (Eimers et al., 2009) and N (Kothawala et al., 2011) concentrations in oligotrophic lakes.

\section{Acknowledgments}

This work was supported by Natural Sciences and Engineering Research Council of Canada (NSERC) Discovery Grants awarded to I.F. Creed and C.G. Trick and an NSERC PGS-D3 award to R.J. Sorichetti. We acknowledge the Ontario Ministry of Environment's Dorset Environmental Research Centre (DESC) for nutrient analysis of the lake samples. We thank Dr. Diane M. McKnight (Institute of Arctic and Alpine Research, University of Colorado Boulder) who provided guidance for the iron modelling work. We thank Ms. Karen Van Kerkoerle (Cartographic Section, Department of Geography, Western University) for producing the map describing the study area. We thank the Central Algoma Freshwater Coalition, Bright Lake Association, Twin Lakes Green Committee as well as G. and B. Campbell for assistance with lake selection, field work and data collection.

\section{References}

Arar E.J. \& Collins G.B. (1997) Method 445.0, In Vitro Determination of Chlorophyll $a$ and Pheophytin a in Marine and Freshwater Algae by Fluorescence. Methods for the Determination of Chemical Substances in Marine and Estuarine Environmental
Matrices, 2nd edn. National Exposure Research Laboratory, Office of research and development, USEPA, Cincinnati.

Bergström A. \& Jansson M. (2006) Atmospheric nitrogen deposition has caused nitrogen enrichment and eutrophication of lakes in the northern hemisphere. Global Change Biology, 12, 635-643.

Callieri C. \& Stockner J. (2000) Picocyanobacteria success in oligotrophic lakes: fact or fiction? Journal of Limnology, 59, 72-76.

Carey C.C., Weathers K.C. \& Cottingham K.L. (2008) Gloeotrichia echinulata blooms in an oligotrophic lake: helpful insights from eutrophic lakes. Journal of Plankton Research, 30, 893-904.

Creed I.F. \& Band L.E. (1998) Export of nitrogen from catchments within a temperate forest: evidence for a unifying mechanism regulated by variable source area dynamics. Water Resources Research, 34, 3105-3120.

Downing J., Watson S. \& McCauley E. (2001) Predicting cyanobacteria dominance in lakes. Canadian Journal of Fisheries and Aquatic Sciences, 58, 1905-1908.

Downs T., Schallenberg M. \& Burns C. (2008) Response of lake phytoplankton to micronutrient enrichment: a study in two New Zealand lakes and an analysis of published data. Aquatic Sciences, 70, 347-360.

Eimers M.C., Watmough S.A., Paterson A.M., Dillon P.J. \& Yao H.X. (2009) Long-term declines in phosphorus export from forested catchments in south-central Ontario. Canadian Journal of Fisheries and Aquatic Sciences, 66, 1682-1692.

Fogg G.E., Stewart W.D.P., Fay P. \& Walsby A.E. (1973) The blue-green Algae. Academic Press, London.

Foley J., DeFries R., Asner G., Barford C., Bonan G., Carpenter S. et al. (2005) Global consequences of land use. Science, 309, 570-574.

Gustafsson J.P. (2001) Modeling the acid-base properties and metal complexation of humic substances with the Stockholm Humic Model. Journal of Colloid and Interface Science, 244, 102-112.

Keeler B.L., Polasky S., Brauman K.A., Johnson K.A., Finlay J.C., O'Neill A. et al. (2012) Linking water quality and well-being for improved assessment and valuation of ecosystem services. Proceedings of the National Academy of Sciences of the United States of America, 109, 18619-18624.

Kerry A., Laudenbach D. \& Trick C. (1988) Influence of iron limitation and nitrogen-source on growth and siderophore production by cyanobacteria. Journal of Phycology, 24, 566-571.

Kinsman R., Ibelings B.W. \& Walsby A.E. (1991) Gas vesicle collapse by turgor pressure and its role in buoyancy regulation by Anabaena flos-aquae. Journal of General Microbiology, 137, 1171-1178.

Kothawala D.N., Watmough S.A., Futter M.N., Zhang L.M. \& Dillon P.J. (2011) Stream nitrate responds rapidly to decreasing nitrate deposition. Ecosystems, 14, 274-286.

Kranzler C., Lis H., Shaked Y. \& Keren N. (2011) The role of reduction in iron uptake processes in a unicellular, 
planktonic cyanobacterium. Environmental Microbiology, 13, 2990-2999.

Marie D., Brussaard C., Partensky F. \& Vaulot D. (1999) Flow Cytometric Analysis of Phytoplankton, Bacteria and Viruses. Current Protocols in Cytometry. John Wiley \& Sons, Inc, New York.

Molot L. \& Brown E. (1986) Method for determining the temporal response of microbial phosphate-transport affinity. Applied and Environmental Microbiology, 51, 524531.

Molot L.A., Li G., Findlay D.L. \& Watson S.B. (2010) Ironmediated suppression of bloom-forming cyanobacteria by oxine in a eutrophic lake. Freshwater Biology, 55, 11021117.

Mur L.R., Skulberg O.M. \& Utkilen H. (1999) Cyanobacteria in the environment. In: Toxic Cyanobacteria in Water: A Guide to their Public Health Consequences. (Eds. I. Chorus \& J. Bartram), pp. 25-54. E \& FN Spon, London.

Murphy T., Lean D. \& Nalewajko C. (1976) Blue-greenalgae - their excretion of iron-selective chelators enables them to dominate other algae. Science, 192, 900-902.

Neilands J. (1995) Siderophores - structure and function of microbial iron transport compounds. Journal of Biological Chemistry, 270, 26723-26726.

Ontario Ministry of the Environment and Energy Standards Development Branch. (1996) Guidance on Sampling and Analytical Methods for Use at Contaminated Sites in Ontario.

Paerl H.W. \& Huisman J. (2009) Climate change: a catalyst for global expansion of harmful cyanobacterial blooms. Environmental Microbiology Reports, 1, 27-37.

Petticrew E.L. \& Arocena J.M. (2001) Evaluation of ironphosphate as a source of internal lake phosphorus loadings. Science of the Total Environment, 266, 87-93.

Ptacnik R., Andersen T. \& Tamminen T. (2010) Performance of the Redfield ratio and a family of nutrient limitation indicators as thresholds for phytoplankton N vs. P limitation. Ecosystems, 13, 1201-1214.

Redfield A.C., Ketchum B.H. \& Richards F.A. (1963) The influence of organisms on the composition of sea-water. The Sea, Vol. 2. Interscience, New York.

Schindler D.W. (2012) The dilemma of controlling cultural eutrophication of lakes. Proceedings of the Royal Society B-Biological Sciences, 279, 4322-4333.

Schneider W. \& Schwyn B. (1987) The Hydrolysis of Iron in Synthetic, Biological, and Aquatic Media. Aquatic Surface Chemistry. John Wiley \& Sons, New York.

Thurman E.M. \& Malcolm R.L. (1981) Preparative isolation of aquatic humic substances. Environmental Science $\mathcal{E}$ Technology, 15, 463-466.

Vrede T. \& Tranvik L.J. (2006) Iron constraints on planktonic primary production in oligotrophic lakes. Ecosystems, 9, 1094-1105.

Watson S.B., McCauley E. \& Downing J.A. (1997) Patterns in phytoplankton taxonomic composition across temperate lakes of differing nutrient status. Limnology and Oceanography, 42, 487-495.

Wilhelm S. (1995) Ecology of iron-limited cyanobacteria: a review of physiological responses and implications for aquatic systems. Aquatic Microbial Ecology, 9, 295-303.

Wilhelm S. \& Trick C.G. (1994) Iron-limited growth of cyanobacteria - multiple siderophore production is a common response. Limnology and Oceanography, 39, 19791984.

Winter J.G., DeSellas A.M., Fletcher R., Heintsch L., Morley A., Nakamoto L. et al. (2011) Algal blooms in Ontario, Canada: increases in reports since 1994. Lake and Reservoir Management, 27, 107-114.

(Manuscript accepted 18 November 2013) 